\title{
Genetic polymorphism of BMP-6 gene (rs267196 and rs267192) in patients with ankylosing spondylitis
}

\section{Ankilozan spondilitli hastalarda BMP-6 (rs267196 ve rs267192) genetik polimorfizmi}

Özlem ÖZTOPUZ1 ${ }^{1}$ Fatma SILAN², Özlem COŞKUN¹, Ayla AKBAL ${ }^{3}$

\section{ABSTRACT}

Objective: Bone morphogenetic proteins (BMPs) have been documented to be associated with ankylosing spondylitis (AS) in several populations. The goal of the present study was to determine the association of the (BMP-6) gene polymorphism (rs267192 and rs267196) with AS and to evaluate the relationships between them based on clinical and laboratory data.

Methods: This study was conducted during August and November 2013 at the physical therapy and rehabilitation outpatient clinics of Çanakkale Onsekiz Mart University Research and Practice Hospital. 42 AS patients and 58 healthy controls were checked with reverse transcription-polymerase chain reaction (RT-PCR) analysis for BMP-6 (rs267192 and rs267196) polymorphism. Clinical data as age, gender, body mass index, C-reactive protein (CRP), erythrocyte sedimentation rate, bath ankylosing spondylitis disease activity index (BASDAI), and HLA-27 positivity were assessed. It was evaluated the relationship between the BMP-6 polymorphism and laboratory findings.

Results: The frequencies of $\mathrm{AA}, \mathrm{AT}$, and TT genotypes for BMP-6 rs267196 were 9.5\% (n=4), 38.1\% $(n=16)$, and $52.4 \%(n=22)$ in AS patients, and $15.5 \%$

\section{ÖZET}

Amaç: Kemik morfogenetik proteinlerinin (BMP'ler) çeșitli popülasyonlarda ankilozan spondilit (AS) ile ilișkili olduğu bildirilmiștir. Bu çalıșmanın amac1, (BMP-6) gen polimorfizminin (rs267192 ve rs267196) AS ile ilișkisini belirlemek ve aralarındaki ilișkileri klinik ve laboratuvar verilerine dayanarak değerlendirmektir.

Yöntem: Bu çalışma, Ağustos 2013 - Kasım 2013 tarihleri arasında Çanakkale Onsekiz Mart Üniversitesi Sağlık Uygulama ve Araştırma Hastanesi Fizik Tedavi ve Rehabilitasyon Polikliniğinde gerçekleștirilmiștir. 42 AS hastası ve 58 sağlıklı kontrol BMP-6 (rs267192 ve rs267196) polimorfizmi için ters transkripsiyonpolimeraz zincir reaksiyonu (RT-PCR) analizi ile kontrol edilmiștir. Klinik veriler olarak yaș, cinsiyet, vücut kitle indeksi, C-reaktif protein (CRP), eritrosit sedimantasyon hızı, bath ankilozan spondilit hastalık aktivite indeksi (BASDAI) ve HLA-27 pozitifliği araștırılmıștır. BMP-6 polimorfizmi ile laboratuvar bulguları arasındaki ilișki değerlendirilmiștir.

Bulgular: BMP-6 rs267196 için sırasıyla AA, AT ve TT genotiplerinin sıklığı AS hastalarında \%9,5 (n= 4), \%38,1 $(n=16)$ ve $\% 52,4 \quad(n=22)$ ve kontrol grubunda $\% 15,5$

${ }^{1}$ Canakkale 18 Mart University, Faculty of Medicine, Department of Biophysic, Canakkale

${ }^{2}$ Canakkale 18 Mart University, Faculty of Medicine, Department of Medical Genetic, Canakkale

${ }^{3}$ Canakkale 18 Mart University, Faculty of Medicine, Department of Physical Medicine and Rehabilitation, Canakkale

İletişim / Corresponding Author : Özlem ÖZTOPUZ

Çanakkale 18 Mart Üniversitesi Tıp Fakültesi, Biyofizik Ana Bilim Dalı, Çanakkale - Türkiye

Tel : +905325851112 E-posta/E-mail : ozlemoztopuz@yahoo.com.tr

Geliş Tarihi / Received : 24.07.2018 Kabul Tarihi/ Accepted : 19.12 .2018

DOI ID : 10.5505/TurkHijyen.2018.91979

Öztopuz Ö, Sılan F, Coșkun Ö, Akbal A. Genetic polymorphism of BMP-6 gene (rs267196 and rs267192) in patients with ankylosing spondylitis.

Turk Hij Den Biyol Derg, 2019; 76(2): 183-194 
$(n=9), 44.8 \%(n=26)$, and $39.7 \% \quad(n=23)$ in controls respectively. BMP-6 rs267196 A allele carriers (versus T ancient allele) had 1.4-fold higher risk and rs267192 T allele carriers (versus $C$ ancient allele) had 1.08-fold higher risk for AS. There was no significant difference between AS and control groups in terms of age, gender and BMI. The CRP and sedimentation levels of the AS group were significantly higher than the control group $(p<0.001)$.

Conclusion: Although some studies have suggested BMP-6 polymorphisms as a possible risk factor for AS, BMP-6, rs267196 and rs267192 alleles were not associated with the disease risk in this study groups.

Key Words: Ankylosing spondylitis (AS), polymorphism, bone morphogenetic protein 6 (BMP-6)
( $n=9), \% 44,8(n=26)$ ve \%39,7 ( $n=23)$ bulunmuștur. BMP-6 rs267196 A allel taşıyıcılar (T alelline karșı) 1,4 kat daha yüksek risk ve rs267192 T allel tașıyıcıları (C alelline karșı) AS için 1,08 kat daha yüksek risk tașıdığı görülmüștür. AS ile kontrol grupları arasında yaș, cinsiyet ve BMI değerleri açısından anlamlı bir fark bulunmamıștır. AS grubunun CRP ve sedimantasyon düzeyi kontrol grubundan anlamlı olarak yüksek olduğu görülmüștür ( $p<0,001)$.

Sonuç: Bu çalıșmalar sonucunda; BMP-6 polimorfizmi AS için olası bir risk faktörü olarak önerilmesine rağmen BMP-6, rs267196 ve rs267192 allelleri çalıșma grubumuzdaki hastalık riski ile ilișkili bulunmamıștır.

Anahtar Kelimeler: Ankilozan spondilit (AS), polimorfizm, kemik morfogenetik proteini (BMP-6)

\section{INTRODUCTION}

Ankylosing spondylitis (AS) is a highly heritable chronic inflammatory disease, which leads to the fusion of sacroiliac and intervertebral joints (1). The disease, which causes AS patients to suffer from a decreased quality of life, is observed more frequently in people at the age of 15 through 35 years and more common in male than female patients. Although the pathophysiology of AS is unknown, it is considered as a polygenic disease. Studies intended to reveal its mechanism have focused on the identification of pathogenic factors, mediators of inflammation and regulators of the disease process. Inflammation caused by the interaction of genetic factors along with various environmental factors is thought to cause damage to the synovial membrane, bones, enthesis sites, and extraarticular tissues such as eye and gastrointestinal mucosa (2). Genetics of AS is advancing rapidly and contributes to our understanding of the etiopathogenesis of the disease. The contribution of genetic effects to the pathogenesis of AS is greater than to other autoimmune-related diseases, such as systemic lupus erythematosus (SLE) and rheumatoid arthritis (RA). To date, $>40$ genetic variants have been identified, including (human leukocyte antigen) HLA alleles, such as HLA-B27, which affect the risk of developing AS (3). HLA-B27 is the major genetic risk factor and biological marker for AS and more than $80 \%$ of cases are positive for the HLA-B27, but many studies suggest that AS is kept under the control by multiple modifier genes and gene-gene interactions $(1,4)$. Genes regulating the pathogenesis of the disease include HLA-B27, ERAP1 (endoplasmic reticulum amino peptidase 1), IL-23 R (interleukin23 receptor), IL-1R2 (interleukin receptor 1, type 2), and ANTXR2 (anthrax toxin receptor), also known as capillary morphogenesis protein 2 (CMG2) $(3,5)$. There is strong evidence on the role of the IL-23 pathway in the pathogenesis of AS. Other pathways associated with AS include the innate and adaptive immune cell differentiation and 
activation of the peptide and gut microbiota. The determination that patients with AS have a different intestinal microbiome is consistent with the theories arising from IL-23-induced interactions between the intestinal microbiome and the host immune system (3).

Genetic studies have developed considerably over the last century and genetic-based approaches to understanding human diseases are changing with technological development. Besides, bone morphogenetic proteins (BMPs) are a group of inflammatory molecules and involved in the superfamily of transforming growth factor- $B$ (TGF-B). BMPs are synthesized from large dimeric proteins in the cytoplasm. Highly conserved molecules and C-terminal peptides are bound to the membrane receptor in target cells and released into extracellular tissues (6). They can induce tissue development and joint morphogenesis participate in embryonic development, cell line determination and osteoblastic differentiation in many aspects(7). BMPs are important growth factors for cartilage and bone homeostasis and may cause chondrocyte hypertrophy, which causes joint fusion and plays a role remodelling in AS joints. Clinical studies have suggested that there is a relationship between skeletal system diseases, BMP pathway and inflammatory process (8). BMP-6 is incorporated into the inflammatory period and promotes osteoblast differentiation from mesenchymal stem cell (9). BMP-2 and BMP-7 have been reported to be overproduced in AS patients. The mechanism of new bone formation in AS is not fully described and it appears that BMP plays an significant role in spinal ankylosis and possibly in a therapeutic target (10). Single nucleotide polymorphisms (SNPs) within BMP-6 are related to ossification. There are few studies on BMP-6 polymorphisms in patients with AS $(4,11,12)$. In the Korean society, a large sample study by Joo et. al. (4), showed that BMP6 gene polymorphism was related to radiographic progression in patients suffering from AS. BMP levels have been showed to vary in AS patients. Some studies reported increased BMP levels in the sera of AS patients, while others level no increase $(10,12)$. Besides, some SNPs are thought to be associated with its diagnosis, progress, and identification of its risks (13). The aim of this study was to investigate the role of BMP-6 polymorphism (rs267192 and rs267196) in patients with AS and to evaluate the relationships between them based on clinical and laboratory data.

\section{MATERIAL and METHOD}

In this case-control study, 42 patients with AS were recruited from the Department of Physical Medicine and Rehabilitation at Çanakkale Onsekiz Mart University (COMU) Research and Practice Hospital, using the Assessment of Spondyloarthritis International Society (ASAS) criteria (14). Clinical data included age, gender, body mass index, C-reactive protein (CRP), erythrocyte sedimentation rate, Bath Ankylosing Spondylitis Disease Activity Index (BASDAI), and HLA-27 positivity. 58 controls were selected from the healthy patients, who were negative according to the AS diagnostic criteria. Ethical approval was received from the local ethics committee of Çanakkale Onsekiz Mart University (Date: October 31, 2013 Ref\#: 050.99-317). Written informed consents were obtained from all the participants.

\section{Genotyping Assay}

Peripheral blood samples were collected in EDTA-containing tubes and stored at $-20{ }^{\circ} \mathrm{C}$ until the analysis. DNA was isolated from the blood samples by spin colon method with the High Pure PCR Template Preparation Kit (Roche). To examine BMP-6 (rs267192 and rs267196) polymorphism, the total reaction, 10 $\mu \mathrm{L}$, consisted of a specific primer probe (LIGHTSNIP BMP-6, rs267196 (Cat\#: 07414161001- TIB MOLBIOL GmbH) and RS267192 (Cat\#: 07414145001 TIB MOLBIOL GmbH), FastStart DNA Master HybProbe master mix (cat\#:12239272001-Roche) and DNA. Quantitative Real-Time PCR outline was monmitored using a Light Cycler 2.0 (Roche, Germany). Denaturation 
was performed at $95^{\circ} \mathrm{C}$ for $10 \mathrm{~min}$, quantitation was carried out with 45 cycles at $95^{\circ} \mathrm{C}$ for $10 \mathrm{sec}$, $60^{\circ} \mathrm{C}$ for $10 \mathrm{sec}$, and $72^{\circ} \mathrm{C}$ for $15 \mathrm{sec}$, and melting was conducted at $95^{\circ} \mathrm{C}$ for $20 \mathrm{sec}, 40^{\circ} \mathrm{C}$ for $20 \mathrm{sec}$ and $85^{\circ} \mathrm{C}$ in 0.2 continuous mode, with cooling at $40^{\circ} \mathrm{C}$. A and $\mathrm{T}$ alleles for rs267192, $\mathrm{C}$ and $\mathrm{T}$ alleles for rs267196 were analyzed with the melting curve analysis at channel 530 after the employment of RT PCR. The study was carried out in Çanakkale Onsekiz Mart University, Faculty of Medicine, Medical Genetic Laboratory.

\section{Statistical analysis}

The SPSS (Statistical Packages of Social Sciences, SPSS for Windows, Version 20.0, Chicago, IC, USA) was utilized for data analysis. Mean, standard deviation, median, minimum and maximum values, frequency, and percentage were used to present the descriptive data. To analyze the data, the parametric Independent Samples t-test and ANOVA test and the non-parametric Mann-Whitney $U$ test and Kruskal Wallis Variance Analysis test were used according to the results of the tests of normality ( $n>50$, Kolmogorov-Smirnov, $n<50$, Shapiro-Wilk). Chi-square test was used to analyze the categorical data. Kolmogorov Smirnov-Z test was used to reveal the differences in HLA-B27 positivity in consideration of the BMP-6 (rs267196 and rs267192 genotypes). A p-value below 0.05 was considered statistically significant.

The major allele frequency model of rs267192 and rs267196 polymorphism has been taken as a reference for the association of AS with SNP alleles. OR value and $95 \%$ confidence intervals were calculated for the reference allele of the predicted minor allele that might be associated with the disease.

In the studied groups, homozygous genotypes common to the control group were identified and taken as a reference, and the association of AS with SNP genotypes was performed. OR values and 95\% confidence intervals were calculated in consideration of the dominant mode (e.g., GT + TT and GG) Medcalc statistical software program. The relationship between the scores of BASDAl was investigated by correlation analyses.

\section{RESULTS}

Demographic and clinical features of the AS and control group are shown in Table 1, 2. No significant differences between AS and control groups were observed in terms of age, gender, and BMI values. Male and female participants in the AS group accounted for $61.9 \%$ and $16 \%$, respectively, while $48.3 \%$ of the control group was male and the remaining $51.7 \%$ was female. CRP and sedimentation level of the AS group was significantly higher than that of the control group $(\mathrm{p}<0.001)$.

We genotyped two polymorphisms of BMP-6 (rs267192 and rs267196) in the 42 patients with AS and 58 control subjects. $\mathrm{p}$ and OR values were calculated to correlate the AS and SNP alleles. The frequencies of alleles and genotypes of BMP-6 were evaluated (rs267196 and rs267196) by allele counting methods (Figure 1).

In the control group, nine participants (15.5\%) were homozygous for the BMP-6 rs267196 (AA genotype), 26 (44.8\%) were heterozygous (AT genotype), while no mutation (TT genotype) was detected in 23 (39.7\%). In the AS group, the breakdown of the AA, AT, and TT genotypes was 4 (9.5\%), 16 (38.1\%), and 22 (52.4\%), respectively (Table 3 ).

The BMP-6 rs267196 allele frequencies for A and $\mathrm{T}$ alleles in AS group were calculated to be $28.6 \%$ $(n=24)$ and $71.4 \%(n=60)$, respectively (Figure 2$)$. The allele frequencies in the control subjects, on the other hand, were found to be $45.8 \%(n=44)$ and $54.2 \%$ $(n=52)$, respectively. The $T$ wild allele frequency was similar in the two groups $(p=0.58, O R=1.40, \mathrm{Cl}$ $(95 \%)=0.43-4.51)$. BMP-6 rs267192 allele frequencies for $\mathrm{C}$ and $\mathrm{T}$ alleles in AS group were $74.4 \%(\mathrm{n}=64)$ and 25.6\% ( $n=22)$, respectively, whereas $C$ and $T$ allele frequencies in the control group subjects accounted 
Table 1. Demographic and clinical characteristics of the participants

\begin{tabular}{|c|c|c|c|c|c|}
\hline \multirow[b]{2}{*}{ Variables } & \multicolumn{2}{|c|}{ AS group $(n=42)$} & \multicolumn{2}{|c|}{ Control group $(n=58)$} & \multirow[b]{2}{*}{$\mathrm{p}$ value } \\
\hline & Mean \pm SD & $\begin{array}{l}\text { Median } \\
\text { (Min-Max) }\end{array}$ & Mean $\pm S D$ & $\begin{array}{l}\text { Median } \\
\text { (Min-Max) }\end{array}$ & \\
\hline Age (years) & $40.14 \pm 9.36$ & $38.50(25.00-60.00)$ & $38.47 \pm 8.60$ & $38.00(23.00-57.00)$ & $0.399^{*}$ \\
\hline BMI $\left(\mathrm{kg} / \mathrm{m}^{2}\right)$ & $27.37 \pm 5.57$ & $26.90(18.00-44.00)$ & $26.21 \pm 3.43$ & $25.75(20.00-35.00)$ & $0.245^{* *}$ \\
\hline CRP (mg/L) & $1.11 \pm 1.14$ & $0.94(0.10-7.05)$ & $0.30 \pm 0.16$ & $0.28(0.10-0.80)$ & $<0.001^{*}$ \\
\hline Sedimentation $(\mathrm{mm} / \mathrm{h})$ & $32.05 \pm 20.02$ & $30.00(7.00-79.00)$ & $13.55 \pm 7.09$ & $13.50(2.00-35.00)$ & $<0.001^{*}$ \\
\hline BASDAI & $3.52 \pm 1.95$ & $3.55(0.00-8.10)$ & - & - & \\
\hline
\end{tabular}

BASDAI: Bath ankylosing spondylitis activity index SD: Standard deviation

$\mathrm{P}^{*}$ : Mann-Whitney U test $\quad{ }^{* *}$ : Independent Samples t-test $\quad$-: BASDAl determined only in AS group

Table 2. The number and percentage of gender in the study groups, HLA-B27 positive and negative number percentages in the AS patient group

\begin{tabular}{lccc}
\hline Variables & AS group $(n=42) \%$ & Control group $(n=58) \%$ & p value \\
\hline Male & $26(61.9)$ & $28(48.3)$ & 0.252 \\
\hline Female & $16(38.1)$ & $30(51.7)$ & \\
HLAB27 & & - \\
HLAB27 Positive & $33(80.5)$ & - \\
HLAB27 Negative & $8(19.5)$ & & \\
\hline
\end{tabular}

p: Chi-square test, - -: HLAB27 was determined only in the AS group.
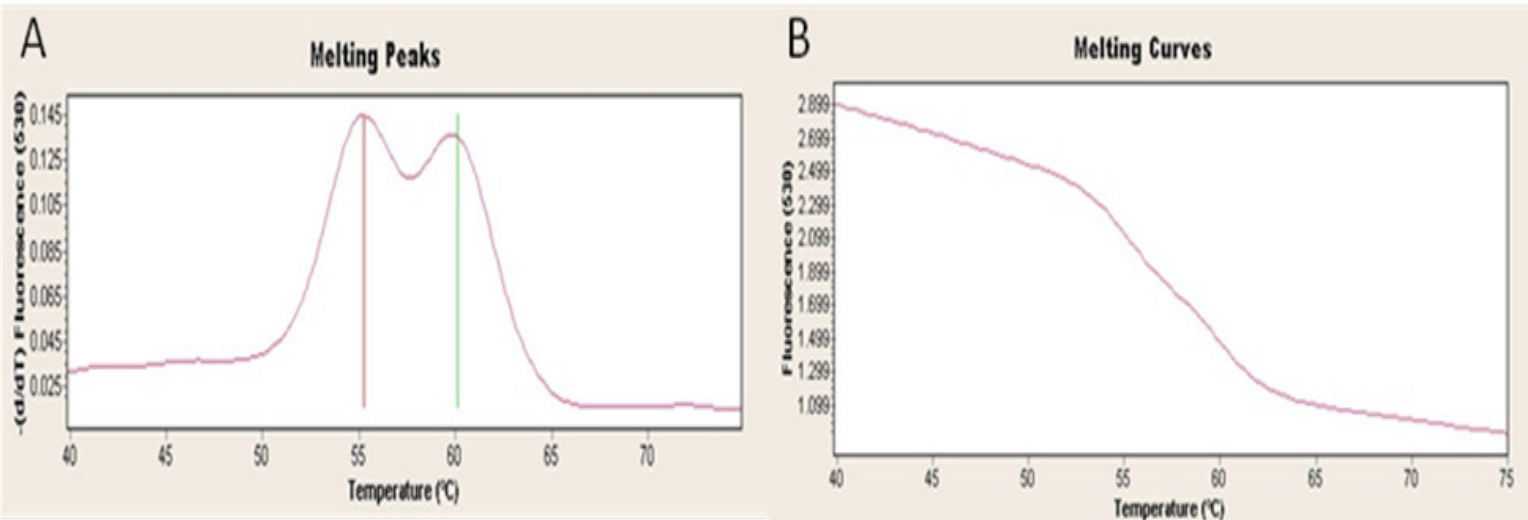

Figure 1. Positive (A) and negative (B) reaction for BMP-6 (rs267196) genotype 
Table 3. Demographic and clinical characteristics of the participants

\begin{tabular}{|c|c|c|c|}
\hline BMP-6 rs267196 & AS Group $\quad(n=42) \%$ & Control & Group $(n=58) \%$ \\
\hline AA & $4(9.5)$ & & $9(15.5)$ \\
\hline AT & $16(38.1)$ & & $26(44.8)$ \\
\hline TT & $22(22)$ & & $23(39.7)$ \\
\hline A & $24(28.6)$ & & $44(45.8)$ \\
\hline $\mathrm{T}$ & $60(71.4)$ & & $52(54.2)$ \\
\hline $\mathbf{P}$ & & 0.58 & \\
\hline Odds Ratio & & 1.40 & \\
\hline $\mathrm{Cl}(95 \%)$ & & 0.43 to 4.51 & \\
\hline BMP-6 rs267192 & AS Group $\quad(n=42) \%$ & Control & Group $(n=58) \%$ \\
\hline CC & $22(50)$ & & $33(56.9)$ \\
\hline CT & $18(40.9)$ & & $22(37.9)$ \\
\hline TT & $2(4.5)$ & & $3(5.2)$ \\
\hline C & $64(74.4)$ & & $88(75.9)$ \\
\hline $\mathrm{T}$ & $22(25.6)$ & & $28(24.1)$ \\
\hline $\mathbf{P}$ & & 0.81 & \\
\hline Odds Ratio & & 1.08 & \\
\hline $\mathrm{Cl}(95 \%)$ & & 0.57 to 2.06 & \\
\hline
\end{tabular}

Med calc statistical software $p<0.0$
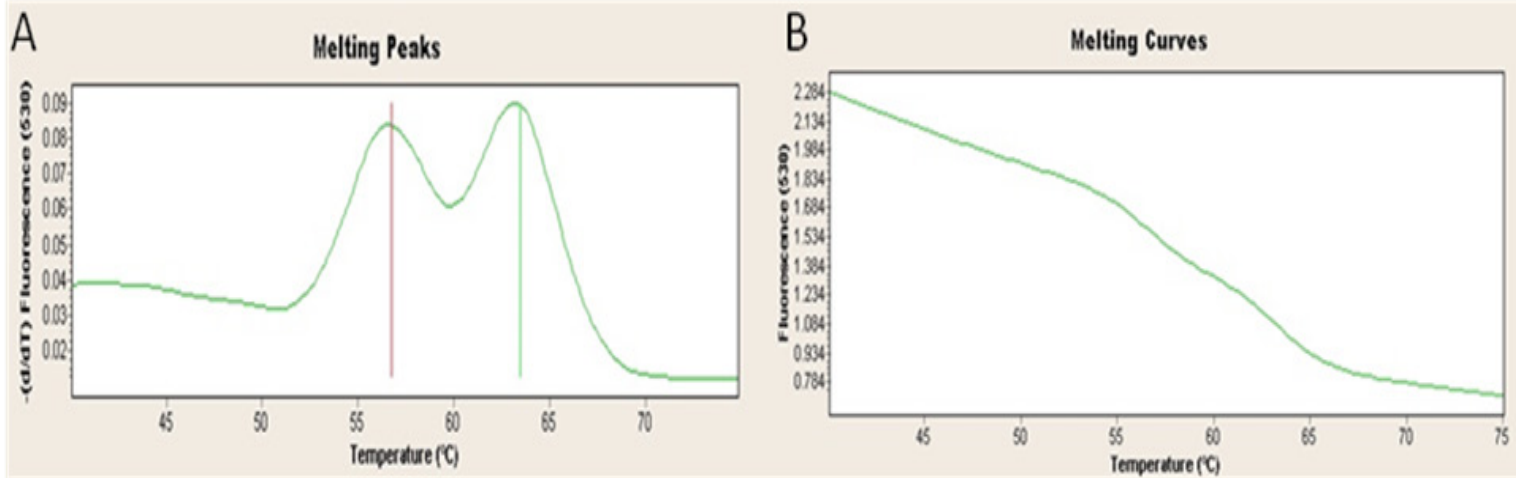

Figure 2. Positive (A) and negative (B) reaction for BMP-6 (rs267196) genotype 
for $75.9 \% \quad(n=88)$ and $24.1 \% \quad(n=28)$, respectively ( $\mathrm{p}=0.81, \mathrm{OR}=1.08,95 \% \mathrm{Cl}=0.57$ to 2.06) (Table 3).

We analyzed the relationship between clinical findings (Sedimentation, CRP, BASDAI score) and BMP6 rs267196 and BMP-6 rs267192 genotypes among AS patients (Table 4). The between-group differences in sedimentation and CRP level were not found significant statiscally $(p>0.05)$.

We further analyzed the association between the values of HLA-B27 positive vs. negative AS patients and BMP-6 polymorphisms (Table 5). In the HLA-B27 positive group, 2 participants (50\%) were homozygous (AA genotype), 12 (75\%) were heterozygous (AT genotype), whereas 19 (90.5\%) were observed to have no mutation (TT) genotype for the BMP-6 rs267196. In the HLA-B27 negative group, the distribution of the AA, AT, and TT genotypes were 2 (50\%), 4 (25\%), and $2(9.5 \%)$, respectively $(p=0.147)$, whereas the genotypic distributions of (BMP-6 rs267192) between the CC, CT, and TT in the HLA-B27 positive group were $19(90.5 \%), 13(72.2 \%)$ and $1(50 \%)$ respectively (Table $5 ; p=0.147)$.

\section{DISCUSSION}

AS is a chronic and progressive disease with still gray areas in the etiology (2). The knowledge about the pathogenesis of AS is limited. Studies intended

Table 4. Differences in sedimentation, CRP, and BASDAl among AS patients ranked by BMP-6 rs267196 and BMP-6 rs267192 genotypes

\begin{tabular}{|c|c|c|c|c|c|c|}
\hline \multirow[b]{2}{*}{ Variables } & \multicolumn{2}{|c|}{ Sedimentation $(\mathrm{mm} / \mathrm{h})$} & \multicolumn{2}{|c|}{ CRP (mg/L) } & \multicolumn{2}{|c|}{ BASDAI } \\
\hline & Mean \pm SD & $\begin{array}{c}\text { Median } \\
\text { (Min-Max) }\end{array}$ & Mean \pm SD & $\begin{array}{c}\text { Median } \\
\text { (Min-Max) }\end{array}$ & Mean \pm SD & $\begin{array}{c}\text { Median } \\
\text { (Min-Max) }\end{array}$ \\
\hline \multicolumn{7}{|c|}{ BMP-6 rs267196 } \\
\hline AA & $14.08 \pm 11.78$ & $10.00(5.00-50.00)$ & $0.50 \pm 0.55$ & $0.37(0.10-2.14)$ & $2.43 \pm 1.49$ & $2.20(1.00-4.30)$ \\
\hline AT & $21.29 \pm 18.35$ & $15.00(4.00-79.00)$ & $0.59 \pm 0.61$ & $0.42(0.10-3.16)$ & $2.91 \pm 1.64$ & $2.80(0.00-5.60)$ \\
\hline$\pi T$ & $23.39 \pm 16.06$ & $17.50(2.00-62.00)$ & $0.72 \pm 1.07$ & $0.37(0.10-7.05)$ & $4.16 \pm 2.07$ & $3.95(0.90-8.10)$ \\
\hline$p$ value & \multicolumn{2}{|r|}{$0.514^{*}$} & \multicolumn{2}{|c|}{$0.674^{*}$} & \multicolumn{2}{|c|}{$0.072^{* *}$} \\
\hline \multicolumn{7}{|c|}{ BMP-6rs267192 } \\
\hline $\mathrm{CC}$ & $21.60 \pm 15.37$ & $16.00(2.00-62.00)$ & $0.65 \pm 0.99$ & $0.34(0.10-7.05)$ & $4.16 \pm 2.07$ & $3.95(0.90-8.10)$ \\
\hline $\mathrm{CT}$ & $21.20 \pm 18.64$ & $15.00(4.00-79.00)$ & $0.65 \pm 0.65$ & $0.42(0.10-3.16)$ & $2.72 \pm 1.64$ & $2.40(0.00-5.60)$ \\
\hline $\mathrm{TT}$ & $19.20 \pm 17.96$ & $16.00(5.00-50.00)$ & $0.45 \pm 0.38$ & $0.37(0.10-1.10)$ & $3.60 \pm 0.99$ & $3.60(2.90-4.30)$ \\
\hline$p$ value & \multicolumn{2}{|r|}{$0.581^{*}$} & \multicolumn{2}{|c|}{$0.663^{*}$} & \multicolumn{2}{|c|}{$0.065^{* *}$} \\
\hline
\end{tabular}

BASDAI: Bath ankylosing spondylitis activity index, SD: Standard deviation, $\mathrm{p}^{*}:$ Kruskal Wallis Variance Analysis test, **: ANOVA test 
Table 5. Difference in HLA-B27 positivity according to the BMP-6 rs267196 and rs267192 genotypes

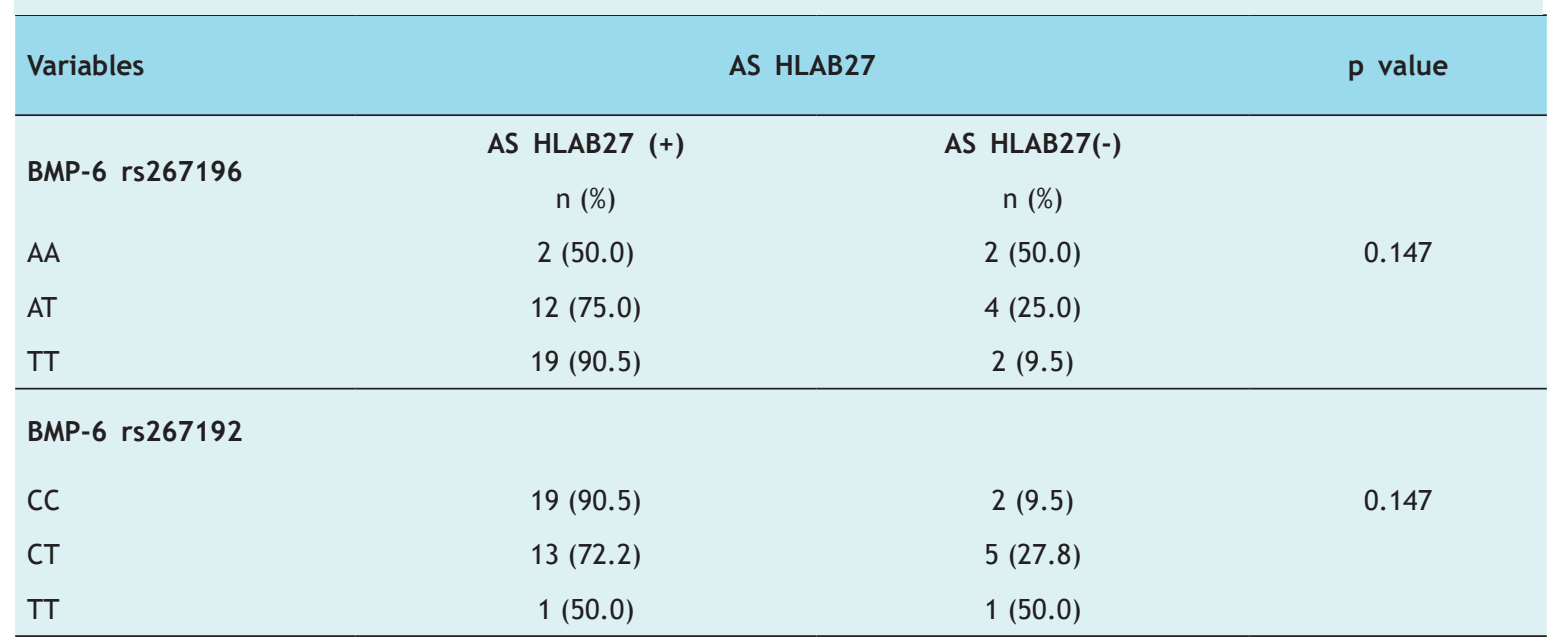

p: Kolmogorov Smirnov-Z test

to reveal its mechanism have focused on the identification of the pathogenic factors, the mediators of the inflammation and regulators of the disease process $(15,16)$. To understand the pathophysiology of this disease, prevention-oriented efforts and management of acute treatment strategies are very important in terms of development. Biochemical and genetic findings have been widely used in the clinical diagnosis of patients with AS. Therefore, a considerable number of recent studies have investigated the laboratory findings on AS in different societies $(13,17,18)$. In recent years, there have been very rapid advances in genetic factors that shad light on the aetiopathogenesis of AS (19). In a study on the identification of multiple risk variants for AS by genotyping immune-related loci, 13 new risky loci and 12 additional AS-associated haplotypes at 11 loci were identified (1). The present research is the first study demonstrating the relationship between the susceptibility to AS and BMP-6 polymorphisms (rs267192 and rs267196). This study aimed to contribute to the efforts intended for early diagnosis of the disease and possible effective treatments by detecting these SNPs and identifying these genetic markers.

There are still no commonly known serum biomarkers to monitor the disease's activity and functional status in patients with AS other than the related CRP and sedimentation level. The CRP and sedimendation levels in the AS group significantly increased in this study $(p<0.001)$. Similarly, in a previous study, CRP, neutrophil count, and platelet values were found significantly higher in AS patients than in the control group (20).

Additionally, we analyzed the relationship between the participants' genetic profiles and hematological parameters. The differences between BMP-6 rs267196 and rs267192 which were observed in sedimentation and CRP levels were not found significant ( $p>0.05$ ) (Table 4). In another study having determined similar results with the present study, Chaouch et al. (18) reported that genetic profile distribution by hematological parameters did not yield a significant difference between the groups with normal genotype and risk genotype. However, the BASDAl index was found to be statistically significant 
in individuals with AA, AT, TT genotype in rs267196 and with CC, CT, TT genotype in rs267196 $(p<0.05)$ (Table 4).

BMPs have an important role in bone development and formation (21). In the presence of BMPs, the precursor cells differentiate into chondrocytes first, then the cartilage structure is built and eventually the bone is formed. Furthermore, they were determined in hypertrophic chondrocytes (21). BMP6 messenger RNA is localized in hypertrophic cartilage and BMP- 6 plays a crucial part in the maintenance and repair of human articular cartilage. Therefore, polymorphisms of BMP-6 are very likely to involve in the regulation of the bone system and necessary for bone metabolism and induce ectopic bone development, pulmonary hypertension in sickle cell and breast cancer growth and progression (4). This study aimed to determine the relationship between BMP-6 gene polymorphism and disease activity in the patients with AS, who were male and female subjects with no additional comorbidities. Up to now, no study has been conducted to investigate BMP-6 (rs267192 and rs267196) polymorphisms and disease activity in Turkish patients with AS.

So far a large number of research articles have been published about BMPs. Ashley et al. (22) investigated the relationship between ACVRL1, BMPR2, and BMP-6 gene polymorphisms and pulmonary hypertension of the TGFB family. They found out that genes in the TGFB pathway contributed to sick cell pathophysiology independently; besides, SNPs of ACVRL1, BMP-6, and ADRB1 genes were also revealed to contribute to pulmonary hypertension development according to the regression model with hemoglobin and age statiscally. In our study, no statistically significant relationship was obtained between BMP-6 (rs267192 and rs267196) polmorphisms in AS patients in comparison to the healthy group. The allele frequencies of BMP-6 rs267192 and rs267196 were similar among AS patients and controls. Contrarily, in a study on AS with BMP6, a relationship was observed between an increased risk of development of syndesmophyte and initial bone formation (4). Further, Joo et al. examined (4) SNPs of genes associated with bone formation, most of which were associated with WNT and BMPs, among them, risk alleles in rs 270378 and rs 1235192 in BMP6 were found to increase the risk of syndesmophyte formation in AS patients. The study by Yan et al. (23) investigated whether BMP-2 is a gene that may cause susceptibility to ossification and found that TG and AT genotype polymorphism was related to the development of posterior longitudinal ligament in their study group.

The present study revealed little difference between the patients with AS and the controls in terms of genotype frequencies of the BMP- 6 rs 267196 . No statistically significant difference was observed in the distribution of the rs267196 genotypes in the AS patients. The frequencies of the AA and AT, TT genotype of BMP-6 (rs267196) were higher in the AS patients than in the controls. The genotype frequencies of BMP-6 (rs267196) AA homozygotes were found higher in AS patients in comparison to TT homozygotes. Similarly, TT homozygotes were also realized to be higher in the patients when compared to AT heterozygotes. In addition, AA homozygotes in comparison with $A A$ and AT genotypes were demonstrated to be higher in the controls than in the patients. Compared to the normal genotype, the risk of disease was discovered to increase 1.4 times for people with AA homozygous mutant genotype vs. TT homozygote. Since the OR value was greater than one, it was predicted that both loci could be associated with AS-induced risks; however, $\mathrm{p}$ value was not considered to be statistically significant ( $p>0.05$ ) (Table 3).

Similar studies are available in the related literature, which evaluate the role of HLA-B27 in AS $(24,25)$. There is evidence that HLA-B27 mutation has many implications in the pathogenesis of spondylarthritis and AS (26). It is accepted that the incidences of the disease are correlated with the HLA-B27 frequency in the geographical area studied and that patients who carry the HLA-B27 gene in their 
blood are more susceptible to this disease. However, some HLA-B27 negative patients too may develop the disease (27). Detection of the non-HLA-B27 genetic factors that are thought to be associated with AS will expose the pathogenesis of the disease (28). In this study, while HLA-B27 positivity was $90.1 \%$, HLA-B27 negative cases accounted for $19.1 \%$. Khan claimed that $8 \%$ of the Northwestern European population had HLA-B27 and more than $90 \%$ of AS patients have this gene (29). Similiarly, Cauli found that HLA-B27 molecules in patients with AS had greater expression than in healthy subjects (30).

Recently some genetic investigations have been carried out to pinpoint the risk of SNP in patients with AS. In the study conducted by Wang over 1150 controls and 797 patients of a Taiwan, ERAP1 variants of rs27037 polymorphism were shown to be associated with the risk of AS disease (31). Similarly, Chaouch and Ulug found an association between rs267196 and a vascular necrosis and osteonecrosis in patients suffering from SCA $(18,32)$. However, as for rs267196 and rs267192 of BMP-6 gene, no significant associations were found in AS patients. In a study over 100 healthy and 100 patient subjects selected from a Central Anatolia, the relationship between HLA-B27, MEFV mutations and ERAP1 polymorphism was shown to play an important role in the pathogenesis of AS (33). The rs3213120, rs11209026, and rs30187 SNPs in the IL12B, IL23R, and ERAP1 genes were studied in AS patients and healthy control group and the possible association of AS disease with these gene regions was analyzed and the rs30187 polymorphism in the ERAP1 gene region and the frequency of heterozygote (CT) alleles were found to be statistically significant in the patients with AS in comparison to the control group ( $\mathrm{p}$ $=0.033$, OR: $2.1,95 \% \mathrm{Cl}: 1.2-3.7$ ) (33). In the present study, BMP-6 (rs267192 and rs267196) polymorphism heterozygote and homozygous allele frequencies were not observed to be statistically significant. Temel (34) investigated the association between AS patients with SS and IL-23R gene polymorphism. In terms of the gene polymorphism of IL-23, the comparison of AS patients and control group yielded an increase in the frequency of rs10889677 mutant genotype (AA) and a decrease in the frequency of rs 11209032 mutant type (AA) ( $p$ values were 0.023 and $<0.001$, respectively). It found that, rs 11209032 genotype may be associated with the development of SS in patients with AS. Akbulut et al., (35) performed genotyping of rs27037 polymorphism in order to determine the genetic risk susceptibility of AS in Malatya, Turkey. They found no association between AS and rs27037 polymorphism. Although the $O R$ value of the $T$ allele was determined to be 1.06 (95\% OR $=0.69-1.65)$, the rs27037 polymorphism could not be associated with the risk of disease due to the $p$ value of 0.776 . In the study by Chen et al. (36) they investigated the relationship between polymorphism in the ERAP1 gene. The ERAP1 gene polymorphism was found to have a great contribution to the formation of AS. On the other hand, it was demonstrated by Zhang et al. (37) in a study conducted over 602 patients and 619 controls from an Asian group in 2013 that rs27037 polymorphism was not associated with the risk of AS disease.

The current study also analyzed the relation between HLAB27 and rs267196 and rs267192 to understand the gene-gene interaction and revealed no significant relationship between gene-gene interaction between HLA-B27 and those SNPs $(p=0.147)$ (Table 5). Evans et al. (38) observed strong evidence for gene-gene interaction between HLA-B27 and rs4349859, rs30187 in ERAP1 ( $p=7.3 \times 10-6)$.

In conclusion; it was seen that the BMP-6 gene is a possible risk factor for the progress of AS. This is the first study to investigate BMP-6 polymorphism in this region, where AS disease is very common. More representative results can be obtained by studying more patients and comparing results from different ethnic groups. Besides, more extensive studies are needed to demonstrate the biological role of BMP-6 in the development of ankylosis in humans with AS. 
ACKNOWLEDGMENT

This study was supported by Çanakkale Onsekiz Mart University Scientific Research Projects with project number TSA-2014-303.

\section{REFERENCES}

1. Cortes A, Hadler J, Pointon JP, Robinson PC, Karaderi T, Leo $\mathrm{P}$, et al. Identification of multiple risk variants for ankylosing spondylitis through high-density genotyping of immune-related loci. Nature genetics, 2013;45(7):730.

2. Coșan F, Gül A. Ankilozan spondilit patogenezi. Turkiye Klinikleri J Int Med Sci, 2007;3(25):13-9.

3. Brown MA, Kenna T, Wordsworth BP. Genetics of ankylosing spondylitis-insights into pathogenesis. Nat Rev Rheumatol, 2016;12(2):81-91.

4. Joo YB, Bang SY, Kim TH, Shim SC, Lee S, Joo KB, et al. Bone morphogenetic protein 6 polymorphisms are associated with radiographic progression in ankylosing spondylitis. PloS One, 2014;9(8):e104966.

5. Burton PR, Clayton DG, Cardon LR, Craddock N, Deloukas P, Duncanson A, et al. Association scan of 14,500 nonsynonymous SNPs in four diseases identifies autoimmunity variants. Nat Gen, 2007;39(11):1329.

6. Grgurevic L, Christensen GL, Schulz TJ, Vukicevic $\mathrm{S}$. Bone morphogenetic proteins in inflammation, glucose homeostasis and adipose tissue energy metabolism. Cytokine \& Growth Factor Rev, 2016;27:105-18.

7. Liao H, Lin Y, Tsai C, Chou T. Bone morphogenetic proteins and dickkopf-1 in ankylosing spondylitis. Scand J Rheumatol, 2018;47(1):56-61.

8. Baldwin C, Nolan VG, Wyszynski DF, Ma Q-L, Sebastiani P, Embury SH, et al. Association of klotho, bone morphogenic protein 6 , and annexin A2 polymorphisms with sickle cell osteonecrosis. Blood, 2005;106(1):372-5.

9. Mahmoud A, Fayez D, Gabal MMA, Hamza SMH, Badr T. Insight on bone morphogenetic protein 7 in ankylosing spondylitis and its association with disease activity and radiographic damage. Electronic Physician, 2016;8(7):2670.
10. Chen $\mathrm{HA}$, Chen $\mathrm{CH}$, Lin YJ, Chen PC, Chen WS $\mathrm{Lu} \mathrm{CL}$, et al. Association of bone morphogenetic proteins with spinal fusion in ankylosing spondylitis. J Rheumatol, 2010;37(10):2126-32.

11. Jane Jr JA, Dunford BA, Kron A, Pittman DD, Sasaki $\mathrm{T}$, Li JZ, et al. Ectopic osteogenesis using adenoviral bone morphogenetic protein (BMP)-4 and BMP-6 gene transfer. MolTher, 2002;6(4):464-70.

12. Wendling $D$, Cedoz JP, Racadot E, Dumoulin G. Serum IL-17, BMP-7, and bone turnover markers in patients with ankylosing spondylitis. Joint Bone Spine, 2007;74(3):304-5.

13. Akbulut E, Erdemir A, Özgen M, Baskin $Y$, Güleç $F$, Turgut Balik D. Genotyping and analysis of rs27037 polymorphism for ankylosing spondylitis. Sigma J Eng Nat Sci, 2015;6(1):117-25

14. van der Linden S, Brown M, Kenna T, Maksymowych W, Robinson P. Ankylosing spondylitis. In: Firestein G, Budd R, Gabriel SE, McInnes IB, O’Dell J, eds. Kelley and Firestein's Textbook of Rheumatology. 10th ed. Amsterdam: Elsevier, 2017.

15. Dakwar E, Reddy J, Vale FL, Uribe JS. A review of the pathogenesis of ankylosing spondylitis. Neurosurg Focus, 2008;24(1):E2. doi: 10.3171/ FOC/2008/24/1/E2.

16. Kim TH, Uhm WS, Inman RD. Pathogenesis of ankylosing spondylitis and reactive arthritis. Curr Opin Rheumatol, 2005;17(4):400-5.

17. Na KS, Kim TH, Rahman P, Peddle L, Choi CB, Inman RD. Analysis of single nucleotide polymorphisms in toll-like receptor 4 shows no association with ankylosing spondylitis in a Korean population. Rheumatol Int, 2008;28(7):627-30.

18. Chaouch L, Kalai M, Jbara MB, Chaabene AB, Darragi I, Chaouachi $D$, et al. Association between rs267196 and rs267201 of BMP6 gene and osteonecrosis among sickle cell aneamia patients. Biomed Pap Med Fac Univ Palacky Olomouc Czech Repub, 2015;159(1):145-9. 
19. Brown MA, Kenna T, Wordsworth BP. Genetics of ankylosing spondylitis-insights into pathogenesis. Nat Rev Rheumatol, 2016;12(2):81.

20. Așkın A. Ankilozan spondilit hastalarında nötrofil/ lenfosit oranı, trombosit/lenfosit oranı ve ortalama trombosit hacminin değerlendirilmesi. Cukurova Med J, 41(3):479-84.

21. Lories RJ, Luyten FP. Bone morphogenetic protein signaling in joint homeostasis and disease. Cytokine \& Growth Factor Rev, 2005;16(3):287-98.

22. Ashley Koch AE, Elliott L, Kail ME, De Castro LM, Jonassaint J, Jackson TL, et al. Identification of genetic polymorphisms associated with risk for pulmonary hypertension in sickle cell disease. Blood, 2008;111(12):5721-6.

23. Yan L, Chang Z, Liu Y, Li Y, He B, Hao D. A single nucleotide polymorphism in the human bone morphogenetic protein-2 gene (109T> G) affects the smad signaling pathway and the predisposition to ossification of the posterior longitudinal ligament of the spine. Chin Med J, 2013;126(6):1112-8.

24. McHugh $\mathrm{K}$, Bowness P. The link between HLA-B27 and SpA-new ideas on an old problem. Rheumatol, 2012;51(9):1529-39.

25. Akbal A, Reșorlu H, Gökmen F, Savaș Y, Zateri C, Sargin B, et al. The relationship between C-reactive protein rs3091244 polymorphism and ankylosing spondylitis. Int J Dis, 2016;19(1):43-8.

26. Tam LS, Gu J, Yu D. Pathogenesis of ankylosing spondylitis. Nat Rev Rheumatol, 2010;6(7):399.

27. Wolf J, Fasching P. Ankylosing spondylitis. Wien Med Wochenschr, 2010;160(9-10):211-4.

28. Çay HF, Kaçar C. Ankilozan spondilit epidemiyolojisi. Turkiye Klinikleri J Immunol- Rheumatol Special Topics, 2011;4(1):1-6.

29. Khan MA. Remarkable polymorphism of HLA-B27: an ongoing saga. Curr Rheumatol Rep, 2010;12(5):33741.

30. Cauli A, Dessole G, Fiorillo M, Vacca A, Mameli A, Bitti P, et al. Increased level of HLA-B27 expression in ankylosing spondylitis patients compared with healthy HLA-B27-positive subjects: a possible further susceptibility factor for the development of disease. Rheumatol, 2002;41(12):1375-9.
31. Wang CM, Ho HH, Chang SW, Wu YJ, Lin JC, Chang PY, et al. ERAP1 genetic variations associated with HLA-B27 interaction and disease severity of syndesmophytes formation in Taiwanese ankylosing spondylitis. Arthritis Research Ther, 2012;14(3):R125.

32. Ulug $P$, Vasavda $N$, Awogbade $M$, Cunningham J, Menzel S, Thein SL. Association of sickle avascular necrosis with bone morphogenic protein 6 . Ann Hematol, 2009;88(8):803-5.

33. Pekacar FS, Akdoğan A, Hayran M, Colak R, Yilmaz E. Ankilozan spondilit ile HLA-B27, MEFV gen mutasyonlar1, ERAP1, IL12B ve IL23R gen polimorfizmleri arasındaki ilișki. Turk Biyokimya Derg, 2014;39(4),482-7.

34. Temel Ș. Primer sjögren sendromu, ankilozon spondilit ve ankilozan spondilitle birlikte sjögren sendromu tanıl hastalarda IL 23 reseptör gen polimorfizminin karșılaștırılması. Tıpta Uzmanlık Tezi, Pamukkale Üni Tıp Fak İç Hast ABD, 2014.

35. Akbulut $E$, Erdemir A, Özgen $M$, Baskin $Y$. Genotyping and analysis of rs27037 polymorphism for ankylosing spondylit. Sigma J Eng \& Nat Sci, 2015; 6(1): 117-125.

36. Chen R, Yao L, Meng T, Xu W. The association between seven ERAP1 polymorphisms and ankylosing spondylitis susceptibility: a metaanalysis involving 8,530 cases and 12,449 controls. Rheumatol Int, 2012;32(4):909-14.

37. Zhang Z, Dai D, Yu K, Yuan F, Jin J, Ding L, et al. Association of HLA-B27 and ERAP1 with ankylosing spondylitis susceptibility in Beijing Han Chinese. HLA, 2014;83(5):324-9.

38. Evans DM, Spencer CC, Pointon JJ, Su Z, Harvey $D$, Kochan G, et al. Interaction between ERAP1 and HLA-B27 in ankylosing spondylitis implicates peptide handling in the mechanism for HLA-B27 in disease susceptibility. Nat Gen, 2011;43(8):761. 